\title{
Sedimentary Characteristics, Origin and Model of Lacustrine Deepwater Gravity Flow Channels
}

\author{
A Case Study from Shahejie Formation in Huanghua Depression, East China
}

\author{
Zhang You \\ Hangzhou Institute of Petroleum Geology \\ CNPC \\ Hangzhou, China \\ e-mail: zhangshiyouda@126.com.
}

Ding Hansheng

Research Institute of Exploration and Development of Daqing Oilfield Company Ltd. CNPC

Daqing, China

e-mail: Daqingdinghansheng@petrochina.com.cn

\author{
Shen Anjiang \\ Hangzhou Institute of Petroleum Geology \\ CNPC \\ Hangzhou, China \\ e-mail: shenaj_hz@petrochina.com.cn \\ Zhang Xianlong \\ Hangzhou Institute of Petroleum Geology \\ CNPC \\ Hangzhou, China \\ e-mail: zhangxl_hz@petrochina.com.cn
}

\begin{abstract}
The Paleocene reservoir of Dagang Oilfield, which is one of the most important and complex faultcontrolled lacustrine reservoirs in China, is located in the north depression of Bohai Basin. With forty years of exploration and development, most large oilfields in East China have generally entered the high water-cut stage. The original deep water lacustrine reservoirs in Dagang Oilfield have, however, experienced significant tectonic and diagenesis throughout its long geological history. These processes have greatly complicated the reservoir properties. Therefore, the fault-controlled deep water lacustrine reservoirs have become a new field of reservoir geology study in China, which is very important in getting a proper knowledge of remaining oil distribution and improving oil recovery rate.

Based on core observation and sedimentary facies analysis, reservoir characteristics of lower Es1 in T34 Block and the main geological factors influencing its physical properties are systematically studied by using a large number of rock thin sections, thin sections, porosity and permeability properties and mercury-injection data etc .It is held that the lower Es1reservoir belongs to mid to low porosity, low to extra-low permeability and fine throat reservoir. Reservoir properties of study area are dominated by diagenesis, and combination of sandstone and mudstone. Among them, carbonate cement, silica cement and clay mineral transformation are the main causes of the poor physical properties, while the corrosion produces substantial secondary porosity and provides favorable reservoir space. Authigenic kaolinite is the dissoluted product of feldspar and debris. Reservoir properties of vertical distribution are controlled by combination of sandstone and shale.
\end{abstract}

Keywords-reservoir property; controlling factors; lower member 1 of Shahejie Formation; T34 Block; Huanghua Depression

\section{INTRODUCTION}

T34, belonging to Dagang Oilfield, one of the most typical complex fault-block oilfields in China, is located in the north depression of Bohai Bay Basin(Fig .1).

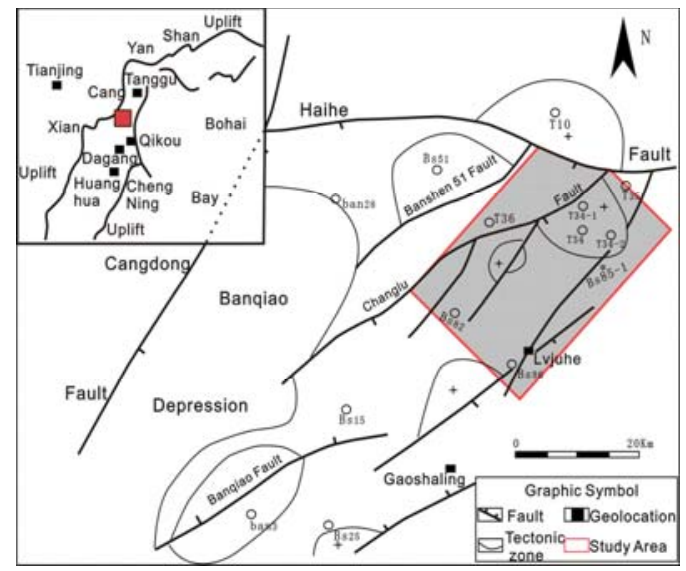

Figure 1. Tectonic zoning map of Changlu

With forty years of exploration and development, most large oilfields in East China have generally entered high water cut stage. However, deepwater reservoirs in Dagang Oilfield have experienced strong tectonic and diagenetic in the long geological period ${ }^{[1-9]}$ (Fig .2), which made reservoir property complex, such as poor injection of injection wells, low recovery of oil wells, quick lateral phase transition of high-quality reservoir etc. Therefore, the deepwater fault-block reservoirs have become a new 
field of reservoir geology study in China, which is very important in getting a proper knowledge of remaining oil distribution and improving oil recovery rate.

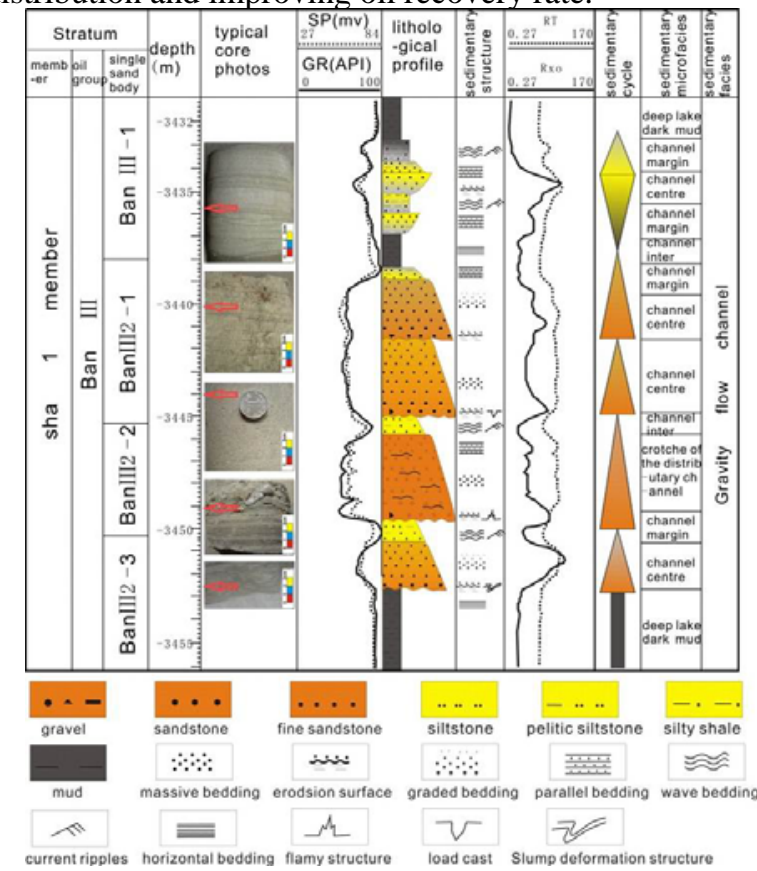

Figure 2. Core succession of gravity flow channel of Es1 from Well Tang34

\section{RESERVOIR PROPERTIES}

We describe a sedimentation pattern approach integrating core (Fig .3), well log and seismic data, to reveal the complex fault-controlled deep water lacustrine reservoirs in Dagang Oilfield. The fault- controlled reservoirs were identified on single wells. And the tectonic evolution history was reconstructed, thus the paleogeomorphology was rebuilt. During the Paleogene, tectonic activity on the Changlu fault that rapid subsidence and deep water environments evolved ${ }^{[10-19]}$. Then deep water lacustrine gravity flow channel sedimentary system was formed in study area with its supply from the north of Yanshan provenance systems and the northwest of the Cangxian uplift ${ }^{[20-25]}$.

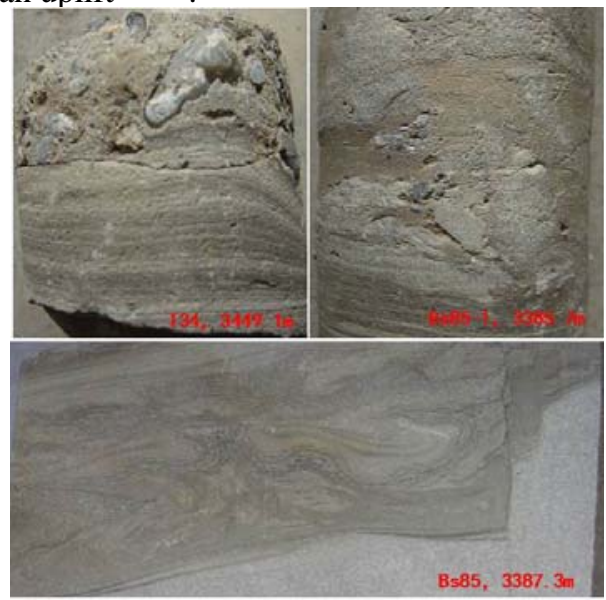

Figure 3. Drilling cores photos from gravity flow channel facies of the lower part of Member 1 of Shahejie Formation of Paleogene in T34 Block
The spatial distribution of the gravity flow channels were predicted with seismic attribute analysis and nonorthogonal wavelet transformation(Fig .4), as it showed an obvious correlation with fault- controlled reservoirs revealed by well data(Fig .5). Deposits in the deep water lacustrine gravity flow channels were divided into channel center microfacies, intersections of distributary channel, channel margin, channel inter and lake mud microfacies. Through the comprehensive analysis of sedimentation, diagenesis, seismic attribute and tectonic evolution history, the fault-controlled deep water lacustrine gravity flow channel sedimentation pattern was established eventually. Our method may be useful in characterizing similar faultcontrolled deep water lacustrine reservoirs in other areas.

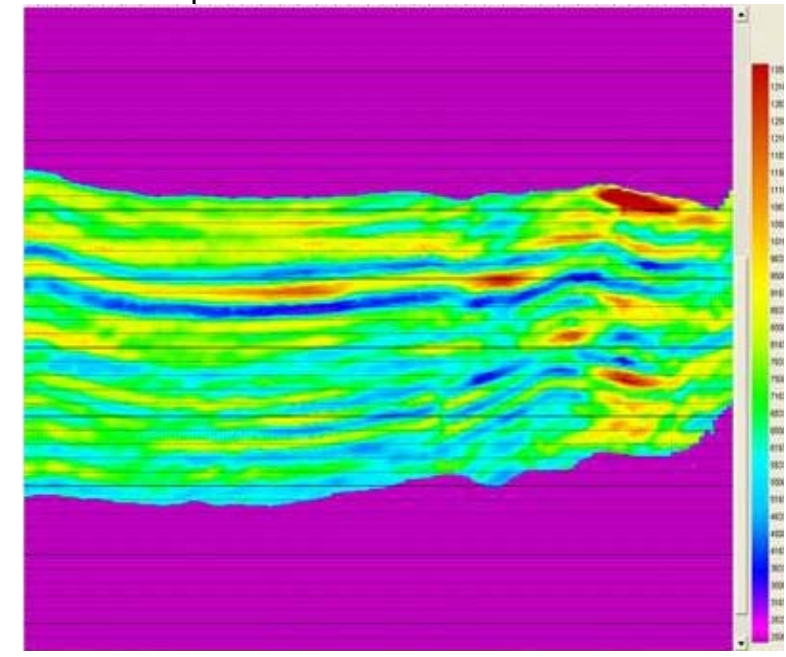

Figure 4. Reservoir inversion of gravity flow channels

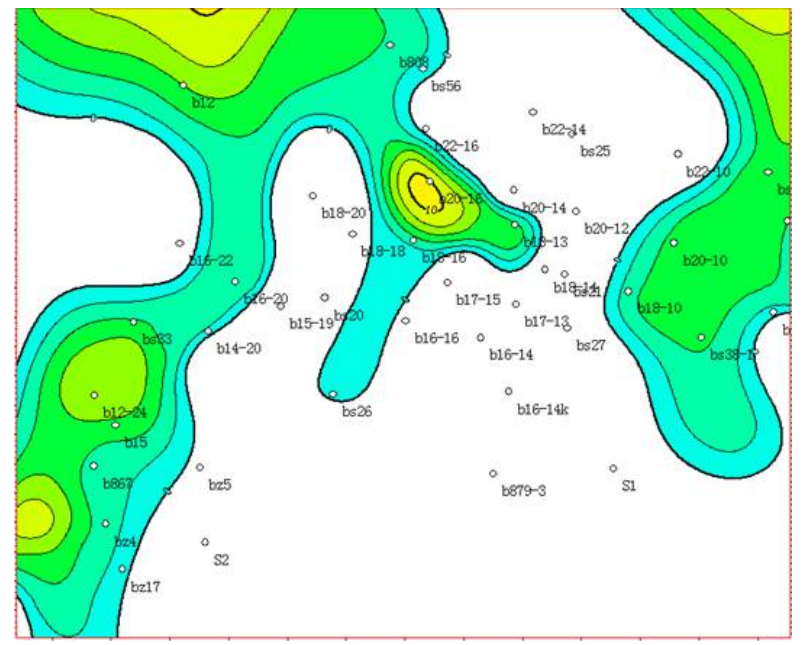

Figure 5. The spatial distribution of the gravity flow channels

Based on core observation and sedimentary facies analysis, the reservoir characteristics of lower Es1 in T34 Block and the main geological factors influencing its physical properties are systematically studied by using a large number of rock thin sections(Fig .6), thin sections, porosity and permeability properties and mercury-injection data etc (TABLE I).It is held that the lower Es1reservoir belongs to mid to low porosity, low to extra-low permeability and fine throat reservoir(Fig .7). 

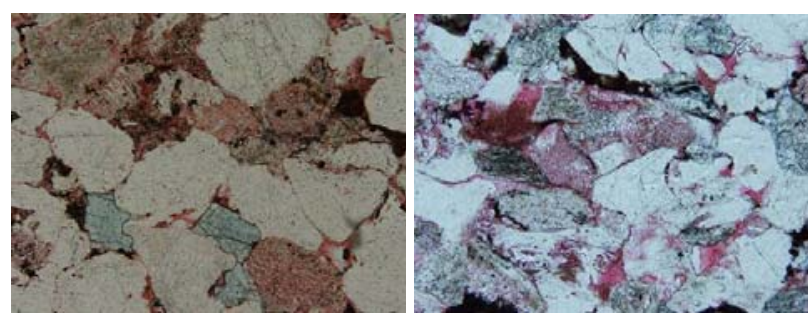

Figure 6. Rock thin sections of Tang34-1,3951.0m,10×, Tang34,3707.0m,20×

TABLE I. MERCURY-INJECTION DATA OF GRAVITY FLOW CHANNEL SANDBODY OF LOWER ES1 IN T34 BLOCK（AFTER MERCURY INJECTION DATA)

\begin{tabular}{|c|c|c|c|c|c|}
\hline Well & $\begin{array}{c}\text { depth/ } \\
\text { m }\end{array}$ & Lithology & $\begin{array}{l}\text { poros } \\
\text { ity/\% }\end{array}$ & $\begin{array}{c}\text { permeabi } \\
\text { lity/x10- } \\
\text { 3um2 } \\
\end{array}$ & $\begin{array}{c}\text { expulsion } \\
\text { pressure } \\
\text { /MPa }\end{array}$ \\
\hline Tang34 & 3435.87 & $\begin{array}{l}\text { middle- } \\
\text { fine } \\
\text { sandstone }\end{array}$ & 19.81 & 10.3 & 0.1383 \\
\hline Tang34 & 3438.14 & $\begin{array}{c}\text { fine } \\
\text { sandstone }\end{array}$ & 17.67 & 0.3 & 0.9991 \\
\hline Tang34 & 3438.5 & siltstone & 14.13 & 0.3 & 1.0326 \\
\hline Tang34 & 3439.07 & $\begin{array}{c}\text { middle } \\
\text { sandstone }\end{array}$ & 20.72 & 41.2 & 0.1019 \\
\hline Tang34 & 3439.68 & $\begin{array}{l}\text { middle- } \\
\text { fine } \\
\text { sandstone }\end{array}$ & 18.91 & 1 & 0.5368 \\
\hline Tang34 & 3441.39 & $\begin{array}{l}\text { middle- } \\
\text { fine } \\
\text { sandstone }\end{array}$ & 18.77 & 0.7 & 0.5366 \\
\hline BS85-1 & 3064.21 & $\begin{array}{c}\text { fine } \\
\text { sandstone }\end{array}$ & 17.11 & 1.3 & 0.2908 \\
\hline BS85-1 & 3381.51 & $\begin{array}{c}\text { middle } \\
\text { sandstone }\end{array}$ & 18.45 & 10.5 & 0.1615 \\
\hline BS86 & 3018.5 & $\begin{array}{c}\text { fine } \\
\text { sandstone }\end{array}$ & 17.67 & 0.4 & 0.6919 \\
\hline BS86 & 3554.04 & $\begin{array}{c}\text { fine } \\
\text { sandstone }\end{array}$ & 15.95 & 4.4 & 0.3218 \\
\hline BS86 & 3557.36 & $\begin{array}{c}\text { middle } \\
\text { sandstone }\end{array}$ & 19.15 & 10.1 & 0.0981 \\
\hline 응 & $\begin{array}{c}1 \\
1 \\
1 \\
1 \\
1 \\
1\end{array}$ & $\begin{array}{l}T_{60} \\
S_{\mathrm{Ha}},\end{array}$ & $T_{40}^{T}$ & $\begin{array}{l}T \\
20\end{array}$ & 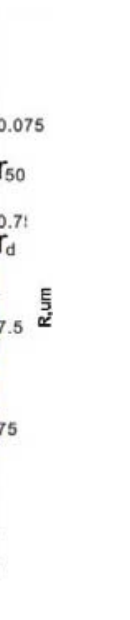 \\
\hline
\end{tabular}

Figure 7. Pore structure features of gravity flow channel sandbody in T34 Block

\section{CONTROLLING FACTORS}

Reservoir properties of study area are dominated by diagenesis, and combination of sandstone and mudstone. Among them, carbonate cement, silica cement and clay mineral transformation are the main causes of the poor physical properties, while the corrosion produces substantial secondary porosity and provides favorable reservoir space ${ }^{[26-29]}$. Authigenic kaolinite is the dissoluted product of feldspar and debris. Reservoir properties of vertical distribution are controlled by combination of sandstone and shale.

\section{CONCLUSIONS}

\section{A. Reservoir properties}

Gravity flow channel reservoir properties belong to medium porosity, low or extra low permeability, fine throat and uneven pore distribution .

\section{B. Controlling factors}

Corrosion of feldspar and cuttings produces substantial secondary porosity, cementation of calcite, dolomite and quartz contribute to destructive effects. Clay minerals have little influence on porosity, but have dramatic influence on permeability. Reservoir properties of vertical distribution are controlled by combination of sandstone and shale.

\section{ACKNOWLEDGMENT}

The authors thank Pro Feng Zengzhao, Zhong Dakang , and Zhu Xiaomin for their comments and suggestions on the original manuscript, and Da Gang Oilfield for making the data available. The work was financially supported by the significant project of the National Science and Technology (grant no. 2008ZX05004-002). The authors are grateful to reviewers, whose comments greatly improved the original manuscript.

\section{REFERENCES}

[1] Wu Chongjun. Sand types of lake basins [J]. Acta Sedimentologica Sinica, 1986, 4(4): 1-27

[2] Zhao Chenglin, Liu Menghui .Early Tertiary Microfacies of Sandbody and Diagenesis in Dongpu Depression. Dongying Shandong: Petroleum University Publishing House, 1988. 9-13

[3] Zhu Xiaomin, Xiong Jihui. Axial gravity flow deposit in Dongpu depression [J]. Journal of the University of Petroleum, China, 1991, 15(5): $1-10$

[4] Wang Liuqi, Jiang Zaixing. Sedimentation in fault-trough gravity channel at Shahejie formation of Dongying depression [J].Journal of the University of Petroleum, China, 1994, 18(3):19-25

[5] Jiang Zaixing, Zhao Chenglin, Liu Menghui. Replaced deposition of gravity flows along moving a deep water dustpan thalweg [J].Petroleum Geology \& Experiment, 1998,10(2):106-115

[6] Yuan Jing, Xu Genwang. Sedimentary facies models of channel turbidites of the fourth member of Paleogene Shahejie Formation in Yong 554 well block,Dongying Sag [J].Coal Geology \& Exploration, 2003,31(6):11-13

[7] Fang Aimin, Li Jiliang, Hou Quanli. Reviews on the study of turbidity currents and relevant gravity flows[J].Geological Review, 1998, 44( 3) : 270-278

[8] Rao Mengyu, Zhong Jianhua, Zhao Zhigen. Overview and prospect on study of turbidity deposits [J]. Coal Geology \& Exploration, 2004, 32(6): 1-4 
[9] Petroleum Geology of Dagang Oilfield Editorial Board. Petroleum geology of China: Volume IV .Dagang oil field [M].Beijing: Petroleum Industry Press, 1991. 74-109

[10] Wang Defa,Zhang Fumin. Sun Yongchuan, etal. Paleogene sedimentary facies and depositional environment of Huanghua Depression[M]. Beijing: Geological Press,1986

[11] Wu Chongjun , Xue Shuhao .China petroleum basin sedimentation[M].Beijing: Petroleum Industry Press,1992. 19-31

[12] JinZhenkui, Zou Yuanrong, Zhang Xiangxiang, etal. Lacustrine Carbonates Sedimentary Facies of the Shahejie Formation of Paleogene in Huanghua Depression[J].Jornal of Palaeogeography,2002,4(3): 11-18

[13] Huang Chuanyan, Wang Hua, Wang Jiahao, etal. Sequence patterns, characteristics of depositional systems and model of reservoirs of fault steep slope belt of the FirstMember of Shahejie Formation in Banqiao Sag [J].Acta Sedimentologica Sinica,2007,25(3):386-390

[14] Huang Chuanyan, Wang Hua, Xiao Dunqing, et al. Depositional character and model of fault-controlling gravity flow in Banqiao Depression [J]. Petroleum Geology and Recovery Efficiency, 2007, 14(6): $14-16$

[15] Reservoir characteristics and controlling factors of the lower part of Member 1 of Paleogene Shahejie Formation in T34 Block, Huanghua Depression[J]. Journal of Palaeogeography, 2012, 14(3): 383-392

[16] Rosovsky.Hydraulics of curving river[J].Journal of Sediment Research,1958,3(1):83-95

[17] MOSER R D,MOIN P.The effects of curvature in wall-bounded turbulent flows[J].J.Fluid Mech.,1987,175:479-510.

[18] Lowe D R. Sediment-gravity flows, II: Depostional models with special reference to the deposits of high-density turbidity currents[J].Journal of Sedimentary Petrology, 1982,52:279-297.
[19] Shanmugam G. Ten turbidite myths[ J].Earth-Science Reviews,2002, 58: 311-341.

[20] Yu Qitai. A study on Remaining oil [J]. Petroleum Exploration and Development, 1997 24(2): 46-50

[21] Li Yang, Wang Duanping, Liu Jianmin. Remaining oil enrichment areas in continental water flooding reservoirs [J]. Petroleum Exploration and Development, 2005, 32(3): 91-96

[22] Gong Changli, Ma Qiao, Yang Bo, ea al. Residual Oil Distribution Law and Development Strategy of Gravity Flow Deposited Reservoirs[J]. Natural Gas Geoscience,, 2008, 19(4): 557-560

[23] Yu Chenglin. The Formation and Distribution of Residual Oil of Putaohua Oilfield [D]. China University of Petroleum, Shandong Doying, 2009: 77-85

[24] Lin Chengyan, YU Chenglin, Dong Chunmei, ea al. Remaining oils distribution in old oilfields:Enrichment of remaining oils in underwater distributary channel crotches [J].Acta Petrolei Sinica, 2011,32 (5) : 829-835

[25] Haldorsen H, Damsleth E. 1993.Challenges in Reservoir Characterization[J]. AAPG Bulletin. 77(4):541-551.

[26] McBride E F. 1987. Diagenesis of Maxon Sandstone (Early Cretaceous), Marathon Region, Texas. In: Diagenetic Quartzarenite,JSP57(10):98-107.

[27] Miall A D. 1988. Reservoir heterogeneities in fluvial sandstone :Lessons from outcrop studies [J].AAPG,72(6):682-697.

[28] Surdam R C. Organic-inorganic interactions and sandstone diagenesis [J]. AAPG, 1989, 73 (1):1-23

[29] Schmidt V M. The role of secondary porosity in the course of sandstone diagenesis [J]. SEPM Special Publication, 1979, 26 : 175-207. 